\title{
Las credenciales y su caducidad
}

\author{
Albert Oriol Bosch
}

Las credenciales, instrumentos de comunicación social, empaquetan mucha más información de lo que aparentan ${ }^{1}$ y cumplen muy variadas funciones. Las credenciales son emitidas por una autoridad reconocida, lo que les confiere credibilidad social.

Según la Real Academia Española, 'credencial', como adjetivo, indica 'que acredita'. Bajo este término se incluyen títulos académicos, certificados de capacitación (p. ej., permiso de conducir), documentos identificativos (documento nacional de identidad, tarjeta sanitaria), de pertenencia (socio de un club), pueden ser de carácter operativo (tarjetas de crédito, lector de biblioteca, de acceso a lugares restringidos), en cantidad y diversidad progresivamente crecientes.

Una credencial puede explicar una historia personal tipificable, es decir, acreditar los logros alcanzados hasta el momento en que se ha emitido la credencial, o bien puede capacitar para la realización de actividades reservadas a los sujetos adecuadamente acreditados por la credencial. Son dos funciones bien distintas que a menudo se han confundido en el pasado. Un título académico, por ejemplo, certifica que el titular ha cubierto los requisitos necesarios para alcanzarlo, acredita que hasta la fecha en que se ha expedido se han cumplido todas las exigencias que su obtención requiere. Nada en el futuro puede cambiar lo que ha ocurrido y que acredita la credencial correspondiente. Es, pues, una credencial con una validez perenne.

Otras credenciales, por el contrario, certifican que el poseedor ha demostrado fehacientemente, en una fecha determinada y ante la autoridad competente, la capacidad para realizar una actuación de manera correcta. Un buen ejemplo de este tipo de credencial lo constituye el permiso de conducción.

\footnotetext{
${ }^{1}$ Así, por ejemplo, el permiso de conducir, además de acreditar que el titular conoce el código de la circulación y es capaz de manejar su automóvil, también lo hace sobre su conducta ética. La penalización por puntos se produce, en general, por desviaciones en la conducta exigible y no por ignorancia o falta de destreza.
}

\section{Time limited credentials}

Credentials are social instruments that provide more information than what is apparent at first glance ${ }^{1}$ and fulfill different functions. Credentials provide social credibility because they are issued by a recognized authority.

According to the Royal Academy of the Spanish Language (RAE), credential, as an adjective, refers to accreditation. Many instruments are included under this term: academic titles, certifications of capabilities (driver licenses), ID cards (club membership), operational cards (credit cards, library cards)..., quantity and variety of which are increasing steadily.

A credential can either describe a typified personal history accrediting the achievements attained up to the moment it is issued, or it may express the authority to perform activities reserved to those holding it. Both functions are rather different, but often they have not been seen as such. An academic title, for example, certifies that the holder has fulfilled the requirements necessary for its granting. Nothing in the future can change this fact, so this is a credential with perennial validity.

On the other hand, other type of credentials certify the holder's capacity to satisfactorily perform a specific set of actions. A good example of this is type of credential is the driver's license. Although this credential also certifies that the holder has fulfilled a certain amount of requirements, it also carries the authorization to perform actions -i.e. driving a carthat are restricted to those who are licensed. This type of credential is time-limited, and it has to be renewed periodically by showing the continued capability to perform correctly.

When 'achievement'-credentials (titles) are mistaken for 'authorization'-credentials (licenses), cre-
Presidente de la Fundación Educación Médica.

Correspondencia: Albert Oriol Bosch. Departamento de Ciencias Fisiológicas. Facultad de Medicina. Universitat de Barcelona. Barcelona, España.

E-mail: aoriolb@terra.es (c) 2011 Educación Médica

\footnotetext{
${ }^{1}$ Driver's licenses, for example, inform not only about the knowledge of traffic regulations and the skills to handle a car, but also about the good character of the licensee as a person willing to follow the rules at all time, as evidenced by the stipulated loss of a license when enough points have been lost due to a repeated disregard of the rules of the road.
} 
Si bien esta credencial también indica que se han cubierto los requisitos exigidos, confiere además la autorización para realizar actuaciones que quienes no están en posesión de dicha credencial no pueden realizar sin delinquir. Se trata de una credencial con fecha de caducidad, como es público y notorio, que exige su renovación periódica, demostrando que se continúa capacitado para actuar correctamente.

Cuando las credenciales que acreditan logros (titulaciones) se confunden con y se utilizan como credenciales que acreditan capacitación se genera el denominado 'credencialismo' o 'titulitis', situación en la que las credenciales (títulos) sustituyen la capacidad demostrada de actuación competente, que puede ser acreditada y certificada con una credencial de vigencia temporal limitada. Esta limitación temporal en la vigencia de la acreditación de la capacidad de actuación competente se debe a la variabilidad a lo largo del tiempo tanto del propio sujeto como de las condiciones y exigencias externas sobre el qué y el cómo deben hacerse las cosas para que la actuación pueda considerarse competente.

Por un lado, la competencia se adquiere en base a la adquisición de rutinas o automatismos, que con el tiempo pueden estereotiparse y perder calidad; por otro, el envejecimiento o las enfermedades, las dependencias o los procesos degenerativos pueden disminuir las capacidades de los sujetos. A ello hay que sumar que los nuevos conocimientos y las nuevas tecnologías disponibles exigen una constante actualización de las capacidades para mantener la actuación al nivel de lo que en cada momento es exigible. En consecuencia, la acreditación de la capacidad para la actuación en ámbitos protegidos, es decir, en aquellos en los que sólo pueden actuar quienes poseen credenciales exigidas, debe ser temporal y necesariamente debe renovarse mediante los controles que se consideren pertinentes.

En las sociedades democráticas, la rendición social de cuentas entre los distintos agentes sociales (stakeholders) es una exigencia de obligado cumplimiento que precisa instrumentos que la hagan factible. Las credenciales son los instrumentos para ello siempre que sean las adecuadas, es decir, que certifiquen capacitación actualizada y no se limiten a la acreditación de los logros alcanzados.

Debe tenerse en cuenta que, en las sociedades democráticas, las normativas que regulan la convivencia articulan contratos sociales tácitos previamente aceptados por sus componentes. Estos contratos sociales tácitos no son necesariamente estables y se adaptan a los cambios que se suceden en el seno de la sociedad. Todos están comprometidos y a ellos deben adaptarse. En cuanto un grupo social dentialism is the result: documents become a substitute for proven capacities, and no consideration is given to the time limit of the credential. The time limit of the authorization-credentials is not arbitrary, but justified by the same reasons that require a license to perform certain activities. Both the individual's capacity to perform, and the requirements that define competent performance could be altered over time as the environment changes.

On the one hand, competence is acquired, in part due to the development of automatisms and routines. On the other hand, as time goes by, the routines can become stereotypes and degrade, on their own or due aging, degenerative diseases, addictions, own neglect and other factors, all of which can diminish personal performance. At the same time, new knowledge and novel technologies become available, as well as social expectancies, demanding a steady updating of one's capabilities in order to maintain performance at the expected level of quality. In consequence, the accreditation of performance in protected domains, those that require a license to perform, should be time-limited and necessarily require its renewal under defined controls at determined time intervals.

Furthermore, democratic societies depend upon social accountability among stakeholders, and credentials are the instruments to ensure such accountability when they properly accredit actual capabilities instead of historical achievements.

It must also be taken into account that in advanced democratic societies, regulations articulate tacit social contracts among stakeholders. These social contracts are not necessarily stable, as they subtly adapt to continuous changes in society. Since all stakeholders are committed to these covenants, they all are supposed to adapt as they evolve. When a social group or an institution loses sight of the social changes occurring in its environment, does not conform to them by renewing its commitment, and does not make it explicit by renewing its credentials, it puts itself in danger of breaking the social contract, and, sooner or later will have to face new social regulations with unforeseen consequences.

What are the implications of all of the above for Medical Schools, Postgraduate Training Programs and Medical Associations? Although this may not be the place to deal with questions as relevant as this one, once the reflection has been made, at least two considerations deserve to be stated:

- All degree- or title-granting educational institutions should first reflect on how they ensure that the credentials they issue have considered and assessed all the elements (knowledge, skills and at- 
o una institución pierde contacto con la realidad de su entorno y no renueva su compromiso con ella o no lo explicita actualizando sus sistemas de comunicación social (credenciales), se corre el riesgo de que el contrato social bajo el cual opera deje de tener vigencia y ello acabe reflejándose en la normativa que se emita en un futuro más o menos próximo, con las consecuencias correspondientes.

De todo lo dicho, ¿qué implicaciones se derivan para las instituciones responsables de la formación de los médicos y para sus corporaciones profesionales?

Aunque probablemente éste no sea el lugar para extraer conclusiones acerca de cuestiones tan relevantes, una vez iniciada la reflexión es necesario por lo menos considerar que:

- Las instituciones cuya actividad formativa acaba certificándose en un título deberían reflexionar si sus esfuerzos garantizan aquello que la certificación del logro presupone (titulo/grado de Medicina y título de Especialista).

- Las instituciones, que actualmente cubren la función de certificar la garantía de calidad en la actuación profesional, deben actualizar sus procesos introduciendo la revalidación periódica con las garantías específicas, y estableciendo las sinergias de cooperación necesarias.

Estas no son cuestiones para cuyo abordaje sobre tiempo. Aunque no pueden tratarse con prisas, sí deben tratarse sin pausa, so pena de perder la iniciativa y que la sociedad decida que haya llegado ya el momento de que sus necesidades se vean atendidas. En tal caso, a nadie debería extrañar que los entes reguladores sean los que atiendan sus cuitas y que lo hagan sin tener en consideración a los negligentes en atender debidamente su responsabilidad social. titudes) society assumes that the credentials in question guarantee.

- The institutions that nowadays provide the license that warrants the quality of professional competence should actualize their procedures by introducing the periodic renewal of professional licenses, and establishing the necessary cooperation synergies.

The time has come to deal with these questions. They cannot be dealt with in a hurry, but they should be dealt without pause in order to avoid radical action by a society that, perceiving that its needs are not being properly met, decides to address the issue through regulation. When that happens, those in charge will not care to attend to the opinions of the up-to-then negligent agents. 